\title{
Canopy phenology of a dry forest in western Brazil
}

\author{
Ragusa-Netto, J. ${ }^{\mathrm{a} *}$ and Silva, RR. ${ }^{\mathrm{b}}$

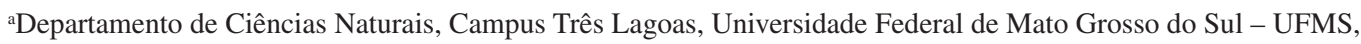 \\ CP 210, CEP 79620-080, Três Lagoas, MS, Brazil \\ ' Instituto de Biociências, Campus da Universidade Federal de Mato Grosso - UFMT, \\ Av. Fernando Correia da Costa, s/n., CEP 78060-900, Cuiabá, MT, Brazil \\ *e-mail: forpus@ceul.ufms.br \\ Received October 26, 2005 - Accepted December 19, 2005 -Distributed August 31, 2007
}

(With 2 figures)

\begin{abstract}
Dry forests are common, although highly threatened in the Neotropics. Their ecological processes are mostly influenced by rainfall pattern, hence their cycles exhibit contrasting phases. We studied the phenology of canopy trees in a primary dry forest in Western Brazil in the foothills of the Urucum mountain chain, in order to improve our knowledge on the functioning of these poorly-known forests. Leaf shedding started in the early dry season and was massive in the latter part of this period. Most leaf loss occurred in dry hills, while wet valleys remained evergreen. Anemochorich and autochorich species predominated in dry hills, presumably due to their tolerance to dry conditions and enhanced exposition to winds, which favour diaspores removal and dispersal. Conversely, zoochorich species dominated the wet valleys. Flowering was intense in the late dry season, the driest period of the year, while fruiting was massive just after the onset of rains, as well as flushing. Therefore, most flowering was unrelated to wet conditions, although such an abiotic factor, potentially, triggered the major fruiting episode, widely comprised by zoochorich species. Anemochorich and autochorich species flowered and fruited in the course of the long dry season. The contrasting environmental conditions present in the hills and valleys determine the arrangement of a mosaic in which patches of zoochorich and evergreen trees alternate with patches of non zoochorich and highly deciduous species. Consequently, species with such syndromes exhibited marked flowering and fruiting patterns, accordingly to the pronounced seasonality.
\end{abstract}

Keywords: canopy trees, deciduous forest, seasonality, dispersal syndromes, flowering and fruiting.

\section{Fenologia do dossel em uma mata seca do oeste brasileiro}

\begin{abstract}
Resumo
Matas secas neotropicais estão amplamente distribuídas, porém sob elevado risco de desmatamento. Os processos ecológicos nesses ambientes são fortemente influenciados pelo clima, sobretudo o padrão de chuvas, de tal forma que seus ciclos apresentam fases muito contrastantes. Nesse estudo, avaliamos a produção de folhas, flores e frutos em uma mata seca do oeste brasileiro situada no sopé do maciço do Urucum. A perda de folhas teve início no começo da estação seca, mas foi massiva ao final desse período, o mais seco do ano. Espécies decíduas predominaram nas escarpas secas, enquanto as perenifólias foram comuns nos vales úmidos. Nas escarpas, espécies anemo e autocóricas eram muito comuns, potencialmente, por serem mais tolerantes à baixa umidade, bem como favorecidas por ventos mais fortes. Porém, eram raras ou mesmo ausentes nos vales úmidos dominados por espécies zoocóricas. A floração foi intensa, exibindo um pico acentuado ao final da estação seca, seguida de um pronunciado pico de frutificação e produção de folhas com o início das chuvas. Dessa forma, enquanto a floração massiva não foi influenciada pelas chuvas, a frutificação e produção de novas folhas estiveram fortemente relacionadas a esse fator abiótico. As espécies anemo e autocóricas floresceram e frutificaram durante a prolongada estação seca, ao contrário da maioria das zoocóricas. As condições ambientais contrastantes dos vales e escarpas, potencialmente determinam um mosaico em que porções altamente decíduas de mata, com predomínio de espécies anemo e autocóricas, se alternam com outras sempre verdes, dominadas por espécies zoocóricas. Além disso, a forte sazonalidade influencia diferentemente espécies com síndromes de dispersão distintas.
\end{abstract}

Palavras-chave: dossel, floresta decídua, sazonalidade, floração, frutificação. 


\section{Introduction}

Dry forests are widespread in the neotropics, and as major features exhibit low trees, scarce understory, and pronounced leaf shedding in the course of the dry season (Bullock and Solís-Magallanes, 1990). In such forests, most plant families include one or exceptionally few species (Gentry, 1995), which usually are patchily distributed (Hubbell, 1979). As dry forests occur in highly seasonal areas, flowering and fruiting pattern are mostly influenced by rainfall pattern (van Schaik et al., 1993). Therefore, with respect to the dispersal pattern, there is a propensity for a balanced number of tree species adapted to animal or non animal seed dispersal (Bullock, 1995).

Taking into account the temporal pattern of water availability as the most important factor determining leaf, flower, and fruit production in the dry forests (Bullock, 1995), their effect on canopy trees is expected as more severe, since this vegetation layer is under harsher environmental conditions in relation to the more wet and dark understory (Lowman and Wittman, 1996). Hence, a major consequence on canopy phenology is a contrasting dynamics, which includes wide modifications of forest microclimate, as well as the relationships with primary consumers, whose activities are also markedly seasonal (van Schaik et al., 1993).

In western Brazil, although under an accelerated deforestation process, dry forests are still common, similar to the dry forests present elsewhere in South America (Murphy and Lugo, 1986). These forests remain almost unstudied, except for neighboring areas in Bolivia (Justiniano and Fredericksen, 2000). The 'Urucum' is a prominent mountain chain within the 'Pantanal' flood plain. In such mountains, dry forests are the major vegetation type from the foothills up to near the top, in which rock fields are present. As phenology studies are a useful tool to improve our knowledge on the functioning of the dry forests, in this study we examined the leaf, flower, and fruit phenology of canopy trees in the foothills of the Urucum mountain chain (Serra Santa Cuz).

\section{Methods}

\subsection{Study site}

This study was developed in the foothills of the Urucum mountain chain (Serra Santa Cruz, Municipality of Corumbá, State of Mato Grosso do Sul, 58 $34^{\prime}$ W and $19^{\circ} 13^{\prime} \mathrm{S}$, elevation $150-200 \mathrm{~m}$ ). The vegetation in this hilly terrain encompasses a gradient of tall dry forest in the foothills, followed by low dry forest up to the timberline $(700-800 \mathrm{~m})$, and rock fields up to the top (approximately $1100 \mathrm{~m}$ ). In the foothills there is a predominance of iron rich soils, and the undulated topography includes wet valleys interspersed with dry hills. The forest canopy in this tract is $12-15 \mathrm{~m}$ tall, but emergent trees may reach 17-18 m. From June to September many tree species drop their leaves (mainly on the hills). The climate exhibits two contrasting seasons (Awa accord- ing to Köppen; Soriano 1997), so that $70-80 \%$ of the annual rainfall (around $1100 \mathrm{~mm}$ ) occurs from November to March (wet season). During the wet season, the average temperature is $26^{\circ} \mathrm{C}$, while during the dry season (April to September), on average $19^{\circ} \mathrm{C}$ is recorded, and in the coldest months frosts may occur (source: mining company in the Urucum mountain chain [Mineração Corumbaense Reunida S/A, Grupo Rio Tinto Brasil]; (Figure 1).

\subsection{Fieldwork procedures}

To select trees to sample leaf, flower, and fruit production, 18 points were positioned $(300 \mathrm{~m}$ apart from each other) along a $6 \mathrm{~km}$ permanent access trail. Consequently, there were eight points in the hills, and 10 in the valleys. At each point the 15 nearest trees with diameters at breast height (DBH) equal to or greater than $30 \mathrm{~cm}$ were numbered with aluminum tags. This criterion was adopted to assure the inclusion of canopy and emergent trees. Also, a tree was selected only if at least $80 \%$ of the crown could be observed from the forest floor. Individual crowns were monitored monthly (between day 20 and 25, from September 2000 to February 2002) for the presence of leaves, flowers and fruits, with the aid of $8 \times 40$ binoculars. The abundance of such organs was ranked on a relative scale ranging from total absence (0) to the full crown capacity (4) of a given phenophase (Fournier, 1974). Thus, for a specific phenophase, the monthly index of resource abundance resulted from the sum of all abundance scores. Tree species were identified by comparison with samples in the herbarium at the Universidade Federal do Mato Grosso do Sul (Corumbá campus) and following Lorenzi (1998). A detailed analysis of dispersal syndromes was beyond the scope of this study since we perform no evaluation on the dispersal process. However, in order to distinguish contrasting diaspores using dispersal syndromes as an organizing tool, we determined the dispersal mode of fruits based on their mesocarp features (shape, texture, color, and size; van der Pijl, 1972). Therefore, we grouped tree species according to dispersal syndromes in order to analyze the relationships between fruit type and phenophase pattern.

\section{Results}

\subsection{Foliar phenology}

The 56 tree species from the phenology sample belong to 26 families (Table 1). Most species (30) as well as trees sampled $(168, \mathrm{~N}=270)$ produced fleshy fruits, while 102 trees from 26 species produced dry fruits (Table 1). Deciduous species predominated in the foothills (54\%), followed by a substantial proportion of species which exhibited partial leaf loss (37\%). Only $9 \%$ were evergreen species, all of them zoochorich. Leaf shedding started in April, so that in May and June some species (mainly Eriotheca roseorum (Cuatrec.) A. Robyns (1963) and Erythrina dominguezii Hassl. 

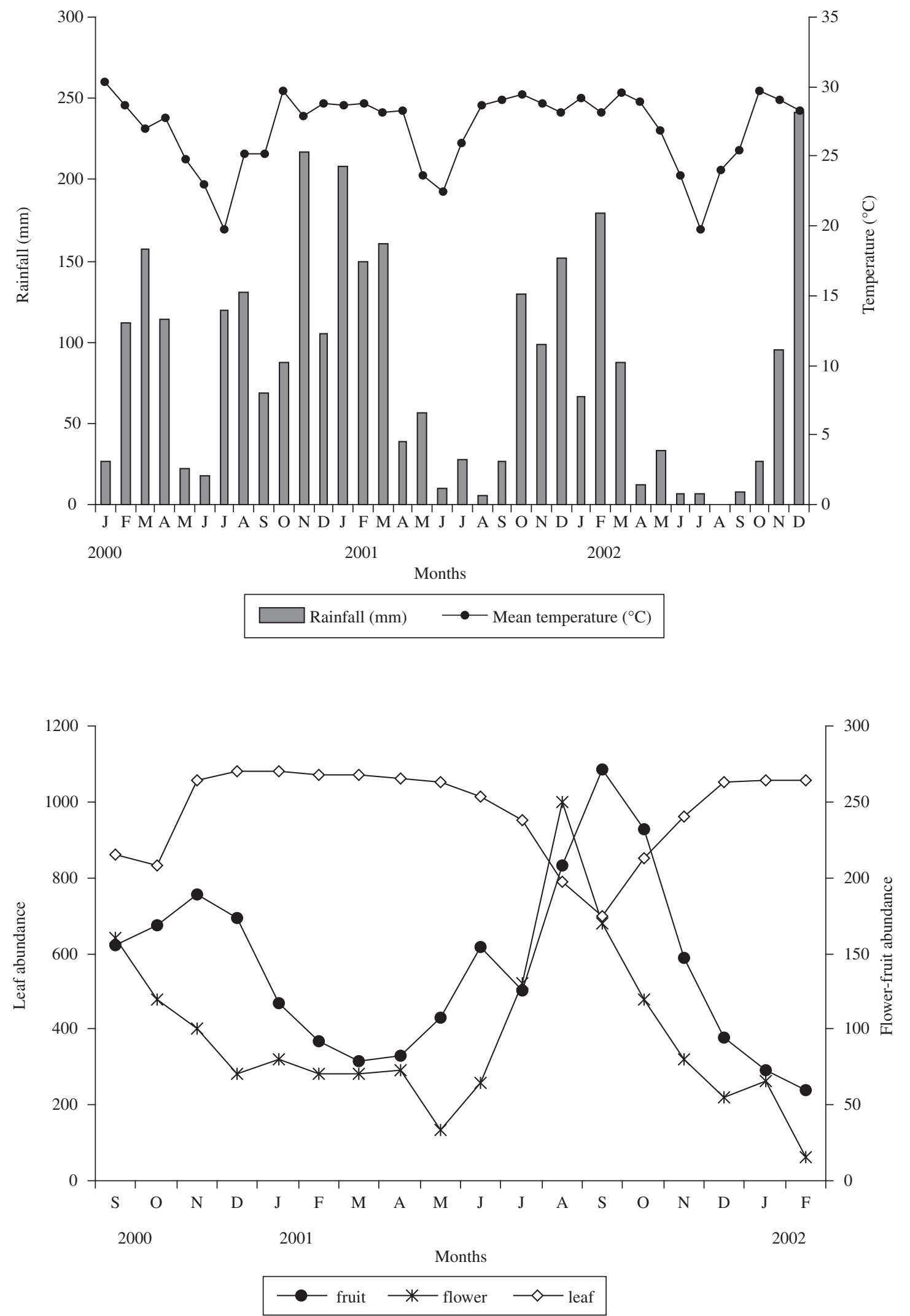

Figure 1. Climate (data from January 2000 to December 2002), and the general patterns of leaf, flower, and fruit abundance ( $N=270$ trees) in the Urucum foothills. 
Table 1. Abundance ( $\mathrm{N}=270$ trees), and fruit type of the tree species $(\mathrm{N}=56)$ in the dry forest in the foothills of the Urucum mountain chain.

\begin{tabular}{|c|c|c|c|c|c|}
\hline Plant taxa & $\mathbf{N}$ & Fruit type & Plant taxa & $\mathbf{N}$ & Fruit type \\
\hline ANACARDIACEAE & & & Guibourtia hymenaefolia & 1 & Zoochorich \\
\hline Astronium fraxinifolium & 14 & Anemoch. & Dipteryx alata & 8 & Zoochorich \\
\hline Myracrodruon urundeuva & 6 & Anemoch. & Enterolobium contortisiliquum & 1 & Autoch. \\
\hline Spondias lutea & 8 & Zoochorich & Erythrina dominguezii & 4 & Autoch. \\
\hline ANNONACEAE & & & Hymenaea courbaril & 4 & Autoch. \\
\hline Annona montana & 2 & Zoochorich & Inga vera & 1 & Zoochorich \\
\hline APOCYNACEAE & & & Lonchocarpus pluvialis & 3 & Autoch. \\
\hline Aspidosperma cylindrocarpon & 1 & Anemoch. & Peltophorum dubium & 4 & Autoch. \\
\hline Aspidosperma subincanum & 13 & Anemoch. & Pterogyne nitens & 1 & Anemoch. \\
\hline ARALIACEAE & & & MELIACEAE & & \\
\hline Schefflera morototoni & 5 & Zoochorich & Cedrela fissilis & 1 & Anemoch. \\
\hline ARECACEAE & & & Guarea guidonia & 24 & Zoochorich \\
\hline Acrocomia aculeata & 4 & Zoochorich & Trichilia catigua & 9 & Zoochorich \\
\hline Attalea phalerata & 7 & Zoochorich & Trichilia elegans & 2 & Zoochorich \\
\hline BIGNONIACEAE & & & MORACEAE & & \\
\hline Jacaranda cuspidifolia & 1 & Anemoch. & Ficus calyptroceras & 1 & Zoochorich \\
\hline Tabebuia impetiginosa & 6 & Anemoch. & Ficus gardneriana & 1 & Zoochorich \\
\hline Tabebuia roseo-alba & 2 & Anemoch. & Ficus gommelleira & 2 & Zoochorich \\
\hline BOMBACACEAE & & & Ficus insipida & 1 & Zoochorich \\
\hline Ceiba boliviana & 1 & Anemoch. & Maclura tinctoria & 1 & Zoochorich \\
\hline Eriotheca roseorum & 7 & Anemoch. & MYRTACEAE & & \\
\hline Pseudobombax longiflorum & 1 & Anemoch. & Eugenia sp. & 1 & Zoochorich \\
\hline BURSERACEAE & & & NYCTAGINACEAE & & \\
\hline Protium heptaphyllum & 43 & Zoochorich & Guapira areolata & 3 & Zoochorich \\
\hline CECROPIACEAE & & & OPILIACEAE & & \\
\hline Cecropia pachystachya & 1 & Zoochorich & Agonandra brasiliensis & 3 & Zoochorich \\
\hline COMBRETACEAE & & & RHAMNACEAE & & \\
\hline Combretum leprosum & 1 & Anemoch. & Rhamnidium elaeocarpum & 1 & Zoochorich \\
\hline Terminalia argentea & 3 & Anemoch. & RUBIACEAE & & \\
\hline FLACOURTIACEAE & & & Coussarea hydrangaeifolia & 5 & Zoochorich \\
\hline Casearia gossypiosperma & 3 & Zoochorich & RUTACEAE & & \\
\hline HIPPOCRATEACEAE & & & Zanthoxyllum chiloperone & 2 & Zoochorich \\
\hline Salacia elliptica & 3 & Zoochorich & SAPOTACEAE & & \\
\hline LAURACEAE & & & Pouteria torta & 20 & Zoochorich \\
\hline Nectandra cissiflora & 1 & Zoochorich & SAPINDACEAE & & \\
\hline LEGUMINOSAE & & & Dilodendron bipinnatum & 3 & Zoochorich \\
\hline Acacia tenuifolia & 1 & Autoch. & STERCULIACEAE & & \\
\hline Acosmium cardenasii & 1 & Autoch. & Sterculia striata & 1 & Zoochorich \\
\hline Albizia niopoides & 2 & Autoch. & TILIACEAE & & \\
\hline Anadenanthera colubrina & 10 & Autoch. & Apeiba tibourbou & 2 & Anemoch. \\
\hline Caesalpinia pluviosa & 4 & Autoch. & Luehea grandiflora & 4 & Autoch. \\
\hline
\end{tabular}

(1922)) were completely leafless. As the dry season progressed leaf loss enhanced dramatically up to the late dry season, when rainfall was usually minimal (Figures 1, 2). Anemochorich and Autochorich species comprised the bulk of deciduous trees, since almost all of them drop their leaves massively, mainly from the middle to the end of the dry season. Common species such as Astronium fraxinifolium Schott (1827), Tabebuia impetiginosa (Mart. ex DC.) Standl. (1936), Myracrodruon urundeuva Allem. (1862), and Anadenanthera colubrina (Vell.) Brenan (1955), became completely leafless, while Aspidosperma subincanum 

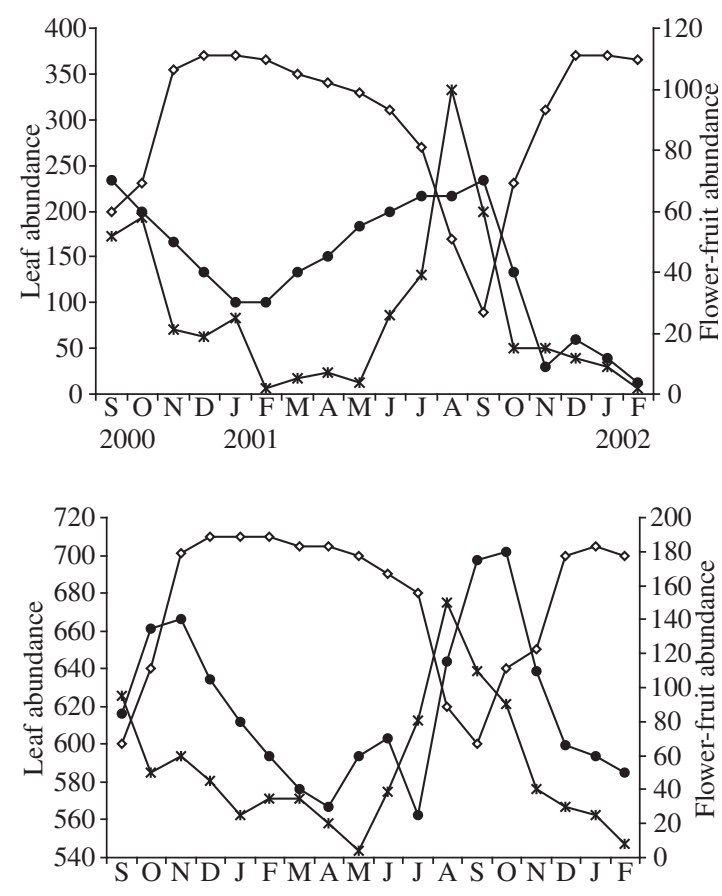

$2000 \quad$ Months 2002

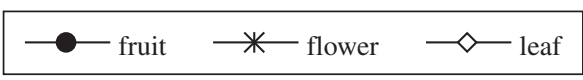

Figure 2. The abundance of leaves, flowers and fruits from anemochorich-autochorich (above), as well as from zoochorich trees (below). (Due to the similar phenology pattern the data from anemochorich and autochorich trees were grouped).

Mart. (1891), and Hymenaea courbaril L. (1753) exhibited partial leaf shedding (Figure 2). Among zoochorich species, pronounced leaf loss occurred in species such as Spondias lutea L. (1762), Dilodendron bipinnatum Radlk. (1878), and in the genus Ficus, while Protium heptaphyllum March. (1873), Guarea guidonia (L.) Sleumer (1956), and Pouteria torta Radlk. (1882) were evergreen (Figure 2). Trees massively produced new leaves from October to December after the first heavy rainfall (Figures 1, 2).

\subsection{Flowering phenology}

Flower production fluctuated substantially during the year, however every month at least some species produced flowers. Flower production declined abruptly during rains, while it was massive in the late dry season (Figures 1, 2). From April to July up to 10 species flowered, whereas up to 22 species did so from August to October. Anemochorich and Autochorich species flowered mainly from the early to the middle of the dry season (39\%, N = 26). Among them Anadenanthera colubrina, Erythrina dominguezii, and Astronium fraxinifolium produced a very large flower crop every year. Only $19 \%$ $(\mathrm{N}=29)$ of zoochorich species flowered in the same period. Zoochorich species produced flowers predomi- nantly from the middle to the late dry season comprising the pronounced flowering peak in August-September (Figure 2). Such a peak arose mainly from flowering of Protium heptaphyllum, and Guarea guidonia. Other zoochorich species important for the flowering pattern were Pouteria torta, and Spondias lutea.

\subsection{Fuiting phenology}

Fruit production was also seasonal with two evident peaks (Figures 1,2). A minor peak was recorded in the middle of the dry season, whereas a very pronounced fruiting peak occurred in the transition from the dry to the wet season (Figures 1,2). The first peak arose mostly from fruiting in Anadenanthera colubrina, Cedrela fissilis Vell. (1829), Caesalpinia pluviosa DC. (1825), and Dipteryx alata Vogel (1837). In this period 17 species fruited, of which only $47 \%$ produced fleshy fruits. On the other hand, the major peak of fruit production resulted from fruiting of abundant species such as Protium heptaphyllum, Guarea guidonia, Pouteria torta, and Spondias lutea. This fruiting peak included up to 20 species, most of which $(70 \%)$ bore fleshy fruits. If only species with fleshy fruits are considered, Protium heptaphyllum was particularly important, since it comprised $43 \%$ of the fruiting peak in October 2001 (Figure 2).

\section{Discussion}

\subsection{Foliar phenology}

During the dry season, although most species at least partially shed their leaves, a semi-deciduous pattern was evident as a result of the large number of evergreen trees. Moreover, even considering that the evaluation of species distribution was beyond the scope of this study, pronounced leaf shedding was clear in the dry hills while evergreen species dominated in the wet valleys. Apparently, in the valleys, soil layer is deeper while the water table is shallower. During the rains, small streams commonly emerged from several points in the valleys. By contrast, exposed rocks were common in the dry hills, and streams occurred in no place during rains. Therefore, wet conditions potentially favored the prolonged lifespan of leaves from trees under a less pronounced water deficit (Borchert, 1994).

In anemochorich and autochorich species, leaf loss started in the early dry season, mainly in those species which flowered in the middle of this period while leafless (e.g. Bignoniaceae and Bombacaceae). Other species which contributed to the major flowering peak became leafless during the driest months, when they flower. These species remain leafless up to the windiest months (August and September) when they bore fruits. As mentioned above, deciduous trees were prominent in the dry hills, in which potentially soil moisture storage was comparatively reduced and wind flow was stronger, favoring diaspore dispersal. 
Among zoochorich species leaf shedding was conspicuous in species present in the dry hills, such as Spondias lutea, Dilodendron bippinnatum, and Ficus calyptroceras. Conversely, the most common species, Protium heptaphyllum, Guarea guidonia, and Pouteria torta, maintained most of their leaves and were very common in the wet valleys, where they exhibit a contrasting pattern in relation to the bare trees in the hills. Therefore, during the dry season this vegetation was arranged as a mosaic in which patches of deciduous trees alternate with evergreen ones, potentially, according to water soil storage (Borchert, 1994; Reich, 1995). The influence of this factor on the life span of leaves was also suggested in the case of some common species which occurred both in hills and valleys (e.g. Protium heptaphyllum, and Spondias lutea). In such species leaf shedding was conspicuously more pronounced on hills in comparison with valleys. As mentioned above, typically, leaf shedding started earlier and was severe on dry hills.

\subsection{Flowering and fruiting phenology}

In Neotropical dry forests, massive flowering usually occurs between the late dry and the early wet season, followed closely by fruit production (Frankie et al., 1974; Bullock and Solis-Magallanes, 1990). As in such forests, tree species may be represented by many individuals, much of the flowering pattern results from their synchronous flower production (Bullock, 1995). This potentially was the case in the Urucum foothills, since the species which comprised most of the flowering peaks, besides being common, fruited during early rains. It is widely accepted that trees time flowering synchronously in order to attract pollinators to enhance pollen flow and/or avoid substantial flower loss to nectar robbers (van Schaik et al., 1993). On the other hand, species with reduced water storage, at dry sites, flower with the first rains, so that rehydration is the major cause for flowering, instead of other environmental cues (Borchert, 1994). The pronounced flowering peaks recorded in this study mostly resulted from flower production of abundant zoochorich species (Protium heptaphyllum, Pouteria torta, and Guarea guidonia), commonly present in the wet valleys. Therefore, much of the major flowering episodes potentially resulted from the adaptations of tree species to their pollen vectors, since the pronounced flowering peak occurred in August and September, the driest month (Figure 1).

In the Urucum foothills, apparently fleshy fruits predominated among canopy trees, a trend found in other Neotropical forests as well (Fenner, 1985; Bullock, 1995). The marked fruiting peak of species with fleshy fruits were potentially conformed to rainfall seasonality, since in the dry forests massive fruit production is usually triggered with the onset of the rains (Frankie et al., 1974; Bullock and Solis-Magallanes, 1990; van Schaik et al., 1993; Funch et al., 2002). Although in the Urucum foothills forest species with fleshy fruits were more common, fruiting was markedly seasonal, so that plentiful fleshy fruit availability was restricted to a few months from the early to the middle of the wet season. Only some species represented by few individuals bore fleshy fruits during the prolonged dry season. Not surprisingly, most of them fruited asynchronously (palms and figs). A substantial fleshy fruit production after the early rains is presumably related to the short period with wet conditions, in forests often subjected to a severe dry season. Then, both seed germination and seedling establishment usually take place in the beginning of the wet season to avoid unfavorable conditions and consequently a higher risk of mortality during the late wet season (van Schaik et al., 1993). Seedlings from many species that fruited during the early wet season, especially those from the abundant Protium heptaphyllum, formed a carpet in some places of the forest floor in the middle of the wet season (pers. obs.).

The wind-dispersed species, on the other hand, bore fruits mainly from the middle to the late dry season, during the windy months. The absence of their leaves favors wind circulation through the bare crowns, which potentially is enhanced at the more exposed hills dominated by such species. Leaf absence and dry conditions also favors seed dispersal in several autochorich species (Bullock and Solis-Magallanes, 1990; van Schaik et. al. 1993; Bullock, 1995). In addition, besides often being present in the dry hills, the emergent trees (mainly anemochorich), also produced fruits during the windiest months when the propensity for efficient seed dispersal is higher (van Schaik et al., 1993). Hence, to conclude, the Urucum foothills forest is arranged as a mosaic of deciduous and evergreen patches in which predominated non-zoochorich and zoochorich trees, respectively. Such areas exhibit a contrasting temporal phenological pattern in response to both rainfall and soil moisture.

\section{References}

BORCHERT, R., 1994. Soil and stem water storage determine phenology and distribution of tropical dry forest trees. Ecology, vol. 75 , p. 1437-1449.

BULLOCK, SH and SOLÍS-MAGALLANES, A., 1990. Phenology of canopy trees of a tropical deciduous forest in Mexico. Biotropica, vol. 22, p. 22-35.

BULLOCK, SH., 1995. Plant reproduction in Neotropical dry forests. In Seasonally dry tropical forests (BULLOCK, S., MOONEY, HA. and MEDINA, E., eds.). Cambridge University Press, Cambridge, p. 277-303.

FENNER, M., 1985. Dispersal. In Seed ecology (M. Fenner, ed.). Chapman \& Hall, London, p. 38-56.

FOURNIER, LA., 1974. Un método cuantitativo para la medición de características fenológicas en arboles. Turrialba, vol. 24 , p. 422-423.

FRANKIE, GW., BAKER, H. and OPLER, PA., 1974. Comparative phenological studies of trees in tropical wet and dry forests in the lowlands of Costa Rica. Journal of Ecology, vol. 62 , p. 881-919. 
FUNCH, LS., FUNCH, R. and BARROSO, GM., 2002. Phenology of gallery and montane forest in the Chapada Diamantina, Bahia, Brazil. Biotropica, vol. 34, p. 40-50.

GENTRY, AH., 1995. Diversity and floristic composition of neotropical dry forests. In BULLOCK, S., MOONEY, HA. and MEDINA, E., eds.). In Seasonally dry tropical forests. Cambridge: Cambridge University Press, p. 146-190.

HUBBELL, SP., 1979. Tree dispersion, abundance, and diversity in a tropical dry forest. Science, vol. 203, p. 1299-1309.

JUSTINIANO, MJ. and FREDERICKSEN, TS., 2000. Phenology of tree species in Bolivian dry forests. Biotropica, vol. 32, p. 276-281.

LORENZI, A., 1998. Árvores Brasileiras: Manual de identificação e cultivo de plantas arbóreas do Brasil. Editora Plantarum, Nova Odessa, 320p.
LOWMAN, MD. and WITTMAN, PK., 1996. Forest canopies: Methods, hypotheses, and future directions. Ann. Rev. Ecol. Syst. vol. 27, p. 55-81.

MURPHY, P. and LUGO, AE., 1986. Ecology of tropical dry forest. Ann. Rev. Ecol. Syst., vol. 17, p. 67-88.

REICH, PB., 1985. Phenology of tropical forests: patterns, causes and consequences. Can. J. Bot., vol. 73, p. 164-174.

SORIANO, BM., 1997. Caracterização Climática de CorumbáMS. Embrapa. (Boletim de Pesquisa, 11), Corumbá. 25p.

van DER PIJL, L., 1972. Principles of dispersal in higher plants. Springer-Verlag, Berlin.

VAN SCHAIK, CP., TERBORGH, JW. and WRIGHT, SJ., 1993. The phenology of tropical forest: adaptative significance and consequences of consumers. Ann. Rev. Ecol. Syst., vol. 24, p. 353-377. 
